\title{
Penerapan Tindakan Precaution Oleh Tenaga Kesehatan Sebagai Upaya Memutus Rantai Infeksi di Rumah Sakit
}

\author{
Awina Milla Shilmy Sitorus \\ awinashilmy@gmail.com
}

\section{Latar Belakang}

Rumah sakit merupakan salah satu tempat pemberian pelayanan kesehatan kepada masyarakat terutama untuk masyarakat yang sedang sakit. Tujuan utama rumah sakit adalah memberikan pelayanan berkualitas demi tercapainya kepuasan pasien yang ditandai dengan berkurangnya keluhan dari pasien, sehingga menunjukan kinerja perusahaan yang tinggi. Pelayanan rumah sakit saat ini tidak saja bersifat kuratif (penyembuhan) tetapi juga pemulihan rehabilitatif). Oleh karena itu, harapan utama masyarakat datang ke rumah sakit adalah untuk mencapai keseimbangan dan kesehatan. (Juwita dalam Hayulita dan Pija, 2014). Tingginya angka kejadian infeksi nosokomial dapat menyebabkan turunnya kualitas mutu pelayanan medis, sehingga perlu adanya pencegahan dan penggendalian (Darmadi, 2008).

Infeksi nosokomial atau yang saat ini disebut sebagai infeksi berkaitan dengan pelayanan di fasilitas kesehatan atau HAIs merupakan suatu masalah serius yang kini menjadi perhatian di banyak negara. Kejadian HAIs dapat menyebabkan morbiditas dan mortalitas meningkat, dan memperpanjang perawatan pasien sehingga meningkatkan biaya pelayanan kesehatan. Upaya yang dapat dilakukan untuk mencegah dan mengendalikan penularan penyakit dari pasien ke petugas kesehatan atau sebaliknya adalah penerapan Standard Precautions atau Kewaspadaan Standar.

Terjadinya infeksi nosokomial di pengaruhi oleh banyak faktor, baik faktor yang ada didalam diri (badan/tubuh) penderita sendiri maupun faktor yang ada disekitarnya. Selain itu ada faktor lain yang dapat mempengaruhi terjadinya infeksi nosokomial yaitu faktor instrinsik yang meliputi umur, jenis kelamin, dan dari faktor keperawatan yang meliputi lamanya hari rawatan, menurunnya standar perawat dan banyaknya penderita, kondisi umum, resiko terapi, adanya penyakit lain serta faktor mikroba patogen juga memberi kontribusi terhadap terjadinya infeksi nosokomial disuatu rumah sakit (Darmadi,2008).

Untuk dapat bekerja secara maksimal, tenaga kesehatan harus selalu mendapatkan perlindungan dari resiko tertular penyakit. Tenaga kesehatan wajib menjaga kesehatan dan keselamatan dirinya dan orang lain serta tanggung jawab sebagai pelaksana kebijakan yang 
ditetapkan di rumah sakit. Tenaga kesehatan juga bertanggung jawab dalam menggunakan sarana yang disediakan dengan baik dan benar serta memelihara sarana agar selalu siap dipakai dan dapat dipakai selama mungkin (Depkes, 2013).

Prosedur tindakan pencegahan universal precaution mutlak harus diterapkan disemua pusat pelayanan kesehatan, seperti ruang gawat darurat, ruang tindakan, ruang triase, ruang observasi dan laboratorium. Berbagai prosedur tindakan keperawatan, baik tindakan invasive maupun non invasive memungkinkan perawat terpapar dengan kuman yang berasal dari pasien melalui cairan tubuh yang mengandung darah. Semua perawat harus menerapkan prosedur tindakan pencegahan universal yang tepat dan konsisten pada setiap saat menjalankan tindakan keperawatan terhadap semua pasien.

Penerapan standard precautions meliputi berbagai prosedur di antaranya yaitu cuci tangan, penggunaan alat pelindung diri, pengelolaan jarum suntik dan alat tajam, penatalaksanaan peralatan (sterilisasi), dan pengelolaan limbah dan sanitasi (Oktarina, 2008). Berdasarkan CDC (Central Disease Control) 2011, komponen utama Standard Precautions meliputi : hand hygiene, penggunaan Alat Pelindung Diri (APD), praktik injeksi aman, penanganan dari peralatan atau permukaan di lingkungan pasien yang potensial terkontaminasi dan respiratory hygiene/etika batuk. Penerapan standar precautions merupakan salah satu bagian dari usaha perawat menyediakan lingkungan bebas dari infeksi serta sebagai upaya perlindungan diri dan pasien terhadap penularan penyakit (Potter \& Perry, 2010). Penerapan standar precautions guna untuk melatih dan membiasakan diri selalu mengutamakan keselamatan dan upaya pengendalian infeksi di rumah sakit terhadap semua pasien.

\section{Metode}

Metode yang digunakan dalam penulisan ini adalah metode kualitatif yang dimana penulis mengumpulkan data sebanyak-banyaknya untuk dianalisis. Tulisan ini didasarkan dengan menganalisis berbagai jurnal atau karya tulis ilmiah yang berfokus pada "Penerapan Tindakan Precaution oleh Tenaga Kesehatan sebagai Upaya Memutus Rantai Infeksi di Rumah Sakit”. Adapun tinjauan literatur yang digunakan dalam penulisan ini adalah buku teks, jurnal atau karya tulis ilmiah yang berasal dari E-book atau Google Scholar dengan syarat literatur yang digunakan terbitan 10 tahun terakhir. Metode dari penulisan ini dilakukan untuk menjelaskan bagaimana pentingnya penerapan tindakan precaution seperti mencuci tangan, penggunaan APD, pengelolaan limbah rumah sakit, dan lainnya sebagai bentuk memutus rantai infeksi yang biasanya sering terjadi di rumah sakit melalui analisa materi yang dikumpulkan dari sumber 
buku teks, jurnal atau karya tulis ilmiah. Penulisan ini dilakukan menggunakan metode kajian bebas terhadap pokok bahasan yang dikumpulkan dari beberapa sumber yang berkaitan dengan pokok bahasan. Pengolahan ini dilakukan dengan metode membandingkan 10 jurnal atau karya tulis ilmiah yang digunakan dan berhubungan dengan pentingnya kualitas proses keperawatan terhadap kepuasan pasien.

\section{Hasil}

Hasil dari pengkajian menggunakan metode penulisan kualitatif adalah menghasilkan suatu pembelajaran bagaimana pentingnya penerapan precaution bagi seluruh tenaga kesehatan seperti dokter, perawat dan lainnya guna memutus rantai infeksi yang sering terjadi di instansi pelayanan kesehatan melalui pengumpulan data berdasarkan buku teks, jurnal atau karya tulis ilmiah.

Kejadian HAIs sebenarnya dapat dicegah bila fasilitas pelayanan kesehatan secara konsisten melaksanakan program PPI. Pencegahan dan Pengendalian Infeksi merupakan upaya untuk memastikan perlindungan kepada setiap orang terhadap kemungkinan tertular infeksi dari sumber masyarakat umumdan disaat menerima pelayanan kesehatan pada berbagai fasilitas kesehatan. Jenis-jenis HAIs yang paling sering terjadi di fasilitas pelayanan kesehatan, terutama rumah sakit, yaitu Ventilator associated pneumonia (VAP), Infeksi Aliran Darah (IAD), Infeksi Saluran Kemih (ISK), dan Infeksi Daerah Operasi (IDO).

Mencuci tangan/Hand Hygiene adalah salah satu indikator yang dapat memutus rantai infeksi atau HAIs. Indikasi kebersihan tangan, yaitu :

- Sebelum kontak pasien;

- Sebelum tindakan aseptik;

- Setelah kontak darah dan cairan tubuh;

- Setelah kontak pasien;

- Setelah kontak dengan lingkungan sekitar pasien.

Selain itu pemisahan limbah rumah sakit juga salah satu indikator pengendalian memutus rantai infeksi. Limbah dibuang kedalam masing tempat sampah sesuai jenisnya. Limbah tersebut dibagi menjadi 4 bagian, yaitu :

- Limbah infeksius: Limbah yang terkontaminasi darah dan cairan tubuh masukkan kedalam kantong plastik berwarna kuning. Contoh: sampel laboratorium, limbah patologis (jaringan, organ, bagian dari tubuh, otopsi, cairan tubuh, produk darah yang 
terdiri dari serum, plasma, trombosit dan lain-lain), diapers dianggap limbah infeksius bila bekas pakai pasien infeksi saluran cerna, menstruasi dan pasien dengan infeksi yang di transmisikan lewat darah atau cairan tubuh lainnya.

- Limbah non-infeksius: Limbah yang tidak terkontaminasi darah dan cairan tubuh, masukkan ke dalam kantong plastik berwarna hitam. Contoh: sampah rumah tangga, sisa makanan, sampah kantor.

- Limbah benda tajam: Limbah yang memiliki permukaan tajam, masukkan kedalam wadah tahan tusuk dan air. Contoh: jarum, spuit, ujung infus, benda yang berpermukaan tajam.

- Limbah cair segera dibuang ke tempat pembuangan/pojok limbah cair (spoelhoek).

\section{Pembahasan}

\section{A. Tingkat kepatuhan mencuci tangan/Hand Hygiene}

Kemenkes (2015) menjelaskan bahwa dasar kewaspadaan universal adalah melalui cuci tangan secara benar, pengunaan alat pelindung, desinfeksi dan pencegahan tusukan alat tajam, dalam upaya mencegah transmisi mikroorganisme melalui darah dan cairan tubuh. Pencegahan utama dilakukan melalui cuci tangan secara benar karena tangan sebagai anggota gerak yang sering digunakan untuk menyentuh pasien. Mencuci tangan adalah proses yang secara mekanik melepaskan kotoran dan debris dari kulit tangan dengan menggunakan sabun biasa dan air. Cuci tangan juga bisa dilakukan dengan menggunakan agen antiseptic atau antimikroba. Agen antiseptic yang sering digunakan adalah penggosok tangan (handrub) antiseptic atau handrub yang berbasis alcohol. Penggunaan handrub antiseptic untuk tangan yang bersih lebih efektif membunuh flora residen dan flora transien daripada mencuci tangan dengan sabun antiseptic atau sabun biasa dan air. Penyebab dari terjadinya infeksi phlebitis bisa disebabkan oleh hygiene petugas dan penunggu pasien yang kurang melakukan cuci tangan dengan benar.

Hand hygiene menjadi salah satu langkah yang efektif untuk memutuskan rantai transmisi infeksi, sehingga insidensi nosokomial dapat berkurang. Pencegahan dan pengendalian infeksi wajib dilakukan oleh perawat, dokter dan seluruh orang yang terlibat dalam perawatan pasien (Fauziah \&Rachmawati, 2018). Hasibuan (2012) menjelaskan bahwa kepatuhan merupakan kesadaran dan kesediaan seseorang untuk menaati semua peraturan dan norma-norma yang berlaku. Kepatuhan yang baik mencerminkan besarnya rasa tanggung jawab seseorang terhadap tugas-tugas yang diberikan kepadanya. Tenaga kesehatan khususnya perawat merupakan salah satu tenaga di rumah sakit yang secara langsung berinteraksi dengan pasien. 
Kepatuhan mencuci tangan perawat merupakan salah satu faktor yang mempunyai pengaruh besar terhadap kesehatan perawat dan pasien dalam pencegahan terjadinya HAIs. Kegagalan untuk melakukan kebersihan tangan dan kesehatan tangan yang tepat dianggap sebagai sebab utama terjadinya infeksi rumah sakit.

\section{B. Tingkat Ketepatan Penggunaan APD}

APD terdiri dari sarung tangan, masker/Respirator Partikulat, pelindung mata (goggle), perisai/pelindung wajah, kap penutup kepala, gaun pelindung/apron, sandal/sepatu tertutup (Sepatu Boot) yang perlu digunakan perawat atau dokter saat berhadapan dengan pasien yang memungkinkan dapat terjadinya penularan. Tujuan Pemakaian APD adalah sebagai melindungi kulit dan membran mukosa dari resiko pajanan darah, cairan tubuh, sekret, ekskreta, kulit yang tidak utuh dan selaput lendir dari pasien ke petugas dan sebaliknya. Indikasi penggunaan APD adalah jika melakukan tindakan yang memungkinkan tubuh atau membran mukosa terkena atau terpercik darah atau cairan tubuh atau kemungkinan pasien terkontaminasi dari perawat atau dokter.

\section{Dekontaminasi Peralatan Perawatan Pasien}

Pada tahun 1968 Spaulding mengusulkan tiga kategori risiko berpotensi infeksi untuk menjadi dasar pemilihan praktik atau proses pencegahan yang akan digunakan (seperti sterilisasi peralatan medis, sarung tangan dan perkakas lainnya) sewaktu merawat pasien. Kategori Spaulding adalah sebagai berikut :

\section{- Kritikal}

Bahan dan praktik ini berkaitan dengan jaringan steril atau sistem darah sehingga merupakan risiko infeksi tingkat tertinggi. Kegagalan manajemen sterilisasi dapat mengakibatkan infeksi yang serius dan fatal.

\section{- Semikritikal}

Bahan dan praktik ini merupakan terpenting kedua setelah kritikal yang berkaitan dengan mukosa dan area kecil di kulit yang lecet. Pengelola perlu mengetahui dan memiliki keterampilan dalam penanganan peralatan invasif, pemrosesan alat, Disinfeksi Tingkat Tinggi (DTT), pemakaian sarung tangan bagi petugas yang menyentuh mukosa atau kulit tidak utuh.

\section{- Non-kritikal}


Pengelolaan peralatan/ bahan dan praktik yang berhubungan dengan kulit utuh yang merupakan risiko terendah. Walaupun demikian, pengelolaan yang buruk pada bahan dan peralatan non-kritikal akan dapat menghabiskan sumber daya dengan manfaat yang terbatas (contohnya sarung tangan steril digunakan untuk setiap kali memegang tempat sampah atau memindahkan sampah). Dalam dekontaminasi peralatan perawatan pasien dilakukan penatalaksanaan peralatan bekas pakai perawatan pasien yang terkontaminasi darah atau cairan tubuh (pre-cleaning, cleaning, disinfeksi, dan sterilisasi) sesuai Standar Prosedur Operasional (SPO) sebagai berikut:

> Rendam peralatan bekas pakai dalam air dan detergen atau enzyme lalu dibersihkan dengan menggunakan spons sebelum dilakukan disinfeksi tingkat tinggi (DTT) atau sterilisasi.

Peralatan yang telah dipakai untuk pasien infeksius harus didekontaminasi terlebih dulu sebelum digunakan untuk pasien lainnya.

> Pastikan peralatan sekali pakai dibuang dan dimusnahkan sesuai prinsip pembuangan sampah dan limbah yang benar. Hal ini juga berlaku untuk alat yang dipakai berulang, jika akan dibuang.

> Untuk alat bekas pakai yang akan di pakai ulang, setelah dibersihkan dengan menggunakan spons, di DTT dengan klorin 0,5\% selama 10 menit.

Peralatan nonkritikal yang terkontaminasi, dapat didisinfeksi menggunakan alkohol 70\%. Peralatan semikritikal didisinfeksi atau disterilisasi, sedangkan peralatan kritikal harus didisinfeksi dan disterilisasi.

> Untuk peralatan yang besar seperti USG dan X-Ray, dapat didekontaminasi permukaannya setelah digunakan di ruangan isolasi.

\section{Pengelolaan Limbah}

Fasilitas pelayanan kesehatan harus mampu melakukan minimalisasi limbah yaitu upaya yang dilakukan untuk mengurangi jumlah limbah yang dihasilkan dengan cara mengurangi bahan (reduce), menggunakan kembali limbah (reuse) dan daur ulang limbah (recycle). Tujuan pengelolaan limbah ini adalah sebagai melindungi pasien, petugas kesehatan, pengunjung dan masyarakat sekitar fasilitas pelayanan kesehatan dari penyebaran infeksi dan membuang bahan-bahan berbahaya (sitotoksik, radioaktif, gas, limbah infeksius, limbah kimiawi dan farmasi dengan aman. Proses pengelolaan limbah dimulai dari identifikasi, pemisahan, labeling, pengangkutan, penyimpanan hingga pembuangan/pemusnahan. 
Agar penerapan standard precautions dapat berjalan dengan baik sesuai hingga dapat mencapai indikator mutu strateginya diantaranya yaitu pertama melakukan pendekatan ke manajer untuk membuat suatu kebijakan, kedua membuat program, ketiga mengusulkan dana serta mencukupi fasilitas, selanjutnya edukasi sosialisasi kepada SDM tentang penerapan kewaspadaan standar, setelah proses pelaksanaan yaitu menganalisa hasil audit, mengevaluasi dan membuat rencana tindak lanjut. Salah satu yang menjadi kelemahan dari kegiatan standard precautions yaitu ketika perilaku SDM yang masih tidak patuh dalam penerapan kegiatan standard precautions. Selain itu, kurangnya fasilitas juga menjadi hambatan dalam penerapan kegiatan standard precautions.

\section{Penutup}

\section{Kesimpulan dan Saran}

Kesimpulan dari penulisan ini adalah terjadinya infeksi nosokomial di pengaruhi oleh banyak faktor, baik faktor yang ada didalam diri (badan/tubuh) penderita sendiri maupun faktor yang ada disekitarnya misalnya seperti berasal dari perawat yang tidak menerapkan Hand Hygiene saat berinteraksi dengan pasien atau faktor lingkungan disekitar rumah sakit. Selain itu, dapat diketahui bahwa dengan mencuci tangan/Hand Hygiene, penggunaan APD dengan benar, dekontaminasi peralatan perawatan pasien, dan pengelolaan apabila diterapkan oleh petugas di setiap pelayanan kesehatan maka akan mencegah terjadi infeksi nosokomial atau HAIs. Agar penerapan standart precaution diterapkan oleh setiap petugas kesehatan diharapkan manajer atau pimpinan rumah sakit dapat menerapkan sebuah kebijakan agar seluruh petugas pelayanan kesehatan dapat menerapkannya.

\section{Referensi}

Basuni, Haris., dkk. (2019). Faktor-Faktor yang Berpengaruh Terhadap Praktik Perawat Dalam Pelaksanaan Universal Precaution di RSUD Brebes. Jurnal Manajemen Kesehatan Indonesia, Volume 7, Nomor 2.

Hayulita, Sri. (2017). Penerapan Universal Precaution: Cuci Tangan Bersih Perawat Berdasarkan Beban Kerja dan Motivasi. AFIYAH, Vol IV, No 2.

Mau, Y. A., dkk. (2018). Hubungan Motivasi Perawat dengan Kepatuhan Perawat dalam Penerapan Universal Precaution di RSU Rajawali Citra Yogyakarta. CARING, Vol 7, No2, 3441. 
Nana, Noviana. (2017). Universal Precaution : Pemahaman Tenaga Kesehatan Terhadap Pencegahan HIV/AIDS. Jurnal Kesehatan Reproduksi, Vol 8, No 2.

Runtu, L. G., dkk. (2013). Faktor-Faktor yang Berhubungan dengan Perilaku Perawat dalam Penerapan Universal Precautions di RSUP Prof. R. D. Kandou Manado. JUIPERDO, Vol 2, No 1.

Safiya, F. I. \& Putra, Ardia. (2019). Hubungan Pengetahuan dengan Sikap Perawat dalam Penerapan Hand Hygiene di Ruang Rawat Inap Medikal Bedah Rumah Sakit. JIM FKep, Volume IV, Nomor 1.

Satiti, A. B., dkk. (2017). Analisis Penerapan Standart Precautions dalam Pencegahan dan Pengendalian HAIs (Healthcare Associated Infections) di RSUD RAA Soewondo Pati. Jurnal Kesehatan Masyarakat (e-journal), Volume 5, Nomor 1.

Simamora, R. H. (2019). Pengaruh Penyuluhan Identifikasi Pasien dengan Menggunakan Media Audiovisual terhadap Pengetahuan Pasien Rawat Inap. Jurnal Keperawatan Silampari, 3(1), 342-351.

Simamora, R. H. (2020). Learning of Patient Identification in Patient Safety Programs Through Clinical Preceptor Models. Medico Legal Update, 20(3), 553-556.

Siregar, S. D. (2019). Hubungan Pengetahuan Perawat Dengan Penerapan Universal Precaution dalam Tindakan Pemasangan Infus diruang Rawat Inap RSUD. DR. PIRNGADI Kota Medan Tahun 2018. Jurnal Mutiara Ners, Volume 2, Nomor 1, 144-149.

Suarnianti. (2017). Pengaruh Pengetahuan dan Sikap Terhadap Penerapan Standart Precautions Mahasiswa Ners STIKES NANI Hasanuddin di Makassar. Global Health Science, Volume 2, Issue 2.

Suarnianti. (2017). Komitmen Perawat dalam Penerapan Standart Precaution di Rumah Sakit Pemerintah Provinsi Sulawesi Selatan. Global Health Science, Volume 2, Issue 4. 